\title{
Recombinant Human Albumin-Human Granulocyte Colony-Stimulating Factor
}

National Cancer Institute

\section{Source}

National Cancer Institute. Recombinant Human Albumin-Human Granulocyte Colony-

Stimulating Factor. NCI Thesaurus. Code C81936.

\begin{abstract}
A long-acting recombinant fusion protein incorporating human serum albumin (HSA)derived and human granulocyte colony stimulating factor (G-CSF)-derived moieties with potential granulopoietic activity. G-CSF, a naturally occurring cytokine, stimulates the production of granulocytes and stem cells in the bone marrow and their release into the blood; it also stimulates the differentiation, function, and survival of neutrophil precursors and mature neutrophils. Albumin fusion may promote an increased serum half-life and bioavailability of the G-CSF moiety of this fusion protein.
\end{abstract}

